\title{
FACING THE CULTURAL CRISIS IN CHILD CARE
}

\author{
Gary Weaver \\ American University, Washington, $D C$
}

There is a crisis in child care today which will only get worse unless we begin to consider the cross-cultural dynamics of child care and try to redress the racial and ethnic imbalance between child care workers and children in group care. The implications of increasing minority children and decreasing minority staff are grave indeed, given the current lack of concern for affirmative action and the worsening economic and social situation for minority children. At the very least, it is imperative that we acknowledge the existence of different cultures and ask ourselves if we are really helping troubled children to become better adjusted or engaging in a form of cultural imperialism which is ultimately destructive to the minority child.

Nonwhite youth are rapidly increasing as a percentage of the overall population and they tend to come from families that are disproportionately confronted with severe economic and social stress. While they are most likely to need professional child care, the institutions they enter are predominantly and increasingly white, both in terms of staff and therapeutic milieu.

According to a recent study, 77 percent of child care workers are white and yet over half of all youth in group care are minorities (Krueger, Lauerman, et al., 1987, 27). All available demographic data suggest that this gap will dramatically widen in the near future and there are no indications that child care agencies are attempting to narrow it. In fact, child care workers themselves seem to be relatively unconcerned. Among the hundreds of workshops and presentations given at various child care conferences and as part of in-service training, certainly no more than a half dozen even mentioned this critical issue.

Imagine these figures and trends reversed. That is, what if child care agencies had 77 percent minority staff and more than 50 percent white, middle class children? Let us further suppose that the differences were increasing - in four or five years, 80 percent of all child care workers are nonwhite and 80 percent of all youth in group care are white. There would be an uproar over the cultural discrepancy. Some might assert that there are too few white role models and claim that the staff could not fully empathize with the social and behavioral culture of white children. There would be concern that white children 
might go through some sort of "culture shock" as they adapt to the nonwhite environment and certainly they would have difficulties readapting to their white communities.

The 1980s have been a period of individual self-centeredness and a lack of concern for the plight of others. Issues of race and ethnicity certainly are not priority concerns of most Americans. The current popular cliche guiding agencies offering social services is colorblindness. This appears fair and egalitarian but it actually amounts to denying that racial and ethnic differences exist and conveniently allows us to ignore the imposition of mainstream (white) norms for appropriate behavior, values, and thought patterns. Colorblindness causes us to view culturally different behavior as pathological and results in cultural homogenization to a white, middle class mold, all under the guise of good child care.

\section{Prevention To Detention}

The economic, social and educational gaps that impact minority children are much greater today than they were at the beginning of the tumultuous $1960 \mathrm{~s}$. When urban ghettos erupted in rage during the $1960 \mathrm{~s}$, the government developed numerous public programs to prevent such explosions from ever occurring again. There was a national effort to cure the diseases of racism, discrimination and poverty among the disadvantaged and prevent such symptoms as school drop-outs, crime, and riots.

Programs that would prevent delinquency and crime, provide greater educational opportunities, and increase employment of minorities, are today being weakened or dismantled. The trend is toward controlling the symptoms of such socio-economic diseases as racism, discrimination and poverty, rather than treating the causes. Crime prevention is being replaced by criminal detention; troubled youth are being removed from schools; the federal government has become an enemy of affirmative action; and bigger jails, courts, and police forces are now fashionable.

During the turmoil of the $1960 \mathrm{~s}$, great efforts were made to allow minorities to compete fairly in the socio-economic and political system and to compensate for previous discriminatory practices and injustices. Especially after the murder of Martin Luther King in 1968 and the resultant urban riots, it was acknowledged by most that it was the responsibility of government to deal with racism, unemployment, educational and economic inequality, and poverty. The goal of creating a "great Society" without racism and discrimination was shared by many who joined together to fight a "War on Poverty." 
The primary target of these programs was minority youth and their families in the form of affirmative action, community development, and educational enhancement programs. While many of these efforts were far too expensive and wasteful, the economic and educational gap between whites and nonwhites was narrowed. Headstart and other such childhood enrichment programs raised both grades and opportunities for nonwhite youth. Many minorities who today live in upper middle class suburban communities are evidence of the success of these programs.

Minority youth took pride in their ethnic and racial backgrounds as various identity movements arose, which, in turn, raised their confidence and self-esteem. Black Power, Indian Power, Hispanic Power, and other such affirmations of the worth of ethnic identity all served to encourage youth to attain their highest economic and educational levels. And the doors seemed to be opening to allow them to reach these aspirations.

However, by the early 1970 s it was obvious that the economy could not simultaneously tolerate a War on Poverty and a War in Vietnam. The Vietnam War cost over a million and a half dollars an hour to fight for over ten years and, at its conclusion, unemployment and inflation began to increase. The economic drain of the Vietnam War, domestic programs, and the oil crises of the 1970s led to the worst recession in over twenty years, which caused many to turn inward and concern themselves with their own personal economic future. The altruism and optimism of the 1960s gave way to self-centeredness and pessimism in the $1970 \mathrm{~s}$.

Our defeat in Vietnam, the Watergate affair, the oil crisis, and the Iran hostage humiliation all contributed to a spirit of cynicism and disillusionment with government. Charles Reich's Greening of America of the 1960s became Christopher Lasch's Culture of Narcissism in the mid-1970s. Politicians began to campaign against government to get elected and advocated the abolition of programs designed to remedy economic, social and political inequality.

A cynical, individualistic, competitive spirit was promoted by various groups and cults which applied a bizarre combination of group relations techniques with a philosophy of Connecticut Yankee individualism. Individual materialistic self-fulfillment could be attained by joining est or selling Amway products, and college students no longer sought to "change the system" but, rather, to "beat the system" by joining the "right" fraternity or sorority. Preppies were only Yuppie larvae who dreamt of excelling in a laissez faire system which was built on me-ism and socio-economic Darwinism.

The vast majority of white Americans believe things have gotten 
better for minorities and no longer perceive them as disadvantaged. Some even suggest that the blame for America's economic problems rests on the shoulders of the poor - "welfare queens" who are ripping off solid, tax-paying citizens and "bums" who are too lazy to work and, instead, live off the sweat of hardworking Americans. Most perceive these "cheats" and "loafers" to be nonwhites who number into the hundreds of thousands and are creating a "culture of poverty" which only spawns more of their kind.

Actually, most people on welfare or below the poverty level are white; well over 90 percent of those on welfare could not work if jobs were available, and the "cheating" is certainly much less than cost overruns for the military. There is little evidence that a "culture of poverty" is developing or has ever existed in this country (Ryan, 1971). This perception really amounts to nothing more than scapegoatism or "blaming the victim." Yet, it does help to justify neglect of the disadvantaged and implies that the poor are responsible for their own fate.

In the early $1980 \mathrm{~s}$, unemployment was nearly 25 percent in Detroit. When asked what the government was going to do about this high unemployment, a government official responded that if people were unemployed in Detroit, they should move to Texas. This was the responsibility of the unemployed, not the federal government. And, when there was an outcry over the many homeless people freezing to death on the streets of the nation's capital, it was suggested by a member of the Administration that these street people actually preferred to be homeless.

While those who are homeless, poor or on welfare are predominantly white, politicians and the media tend to portray them as nonwhite. And, the proportion or percentage of nonwhites who are homeless, poor or on welfare is much greater than whites. Nonwhites are much more likely to be unemployed and suffer from other forms of socio-economic malaise than whites. Programs which were designed to eliminate these social ills benefitted whites in greater numbers than nonwhites, yet the popular perception is that they were simply handouts for nonwhites who were solely responsible for their own misfortunes and the drain on the pocketbook of hardworking, middle class, white Americans.

"Blaming the victim," "benign neglect," "scapegoatism," and "culture of poverty" are phrases that aptly reflect the current mood of mainstream Americans toward the greatly disproportionately poor, unemployed, undereducated, and urbanized minority Americans. Fewer jobs exist for the unskilled today than at any time in the past twenty years; unemployment among minorities is well over twice the rate of whites; the education gap between nonwhites and whites is 
wider than at the end of the 1960s; each year a smaller percentage of minorities attend college; bilingual education is being cut; and there are strong political backlashes against government programs designed to help minorities and immigrants. To assert that "they" are responsible for their own fate or that they can "pull themselves up by their bootstraps" is callous and cynical.

The anti-civil rights, anti-affirmative action posture taken by the Reagan administration has emboldened racists, and the social climate in America today suggests that racism is tolerable again, and even fashionable in some neighborhoods. The moderate, black columnist Carl R. Rowan asserts that "naked, violent racism is on the upsurge in America." In 1986, New York Mayor Edward I. Koch asked for a national commission on racism and a local conference to address the issue of racial problems in New York City. In a December 28, 1986 appearance on CBS' "Face the Nation," Koch said he believes "that since the Kerner Commission of 1968, that racism has decreased in this country." However, he noted that "we still have the cancer of racism. Anyone who says the country ... is free of racism is not telling the truth or is simply an ostrich whose head is buried in the sand." Certainly, racism plays a part in the current attitude toward the disadvantaged who comprise a greater percentage of minority populations.

Educational enhancement and enrichment programs, community development efforts, and job placement training are daily being weakened or eliminated, yet these programs might well prevent unemployment, crime, poverty and much of the social and political malaise confronting many Americans. In child care, preventive programs and early treatment approaches are no longer fashionable. The current trend is toward punishment as a deterrent, building larger detention facilities, preadjudication centers to hold youth, and treating minors as adults. We are perhaps the only country on earth that has adolescents on death row.

Hardline cure-all panaceas such as "tough love" and the "scared straight" Rashway prison project are cheap, appear efficient, and relieve everyone of considering the root causes of juvenile crime. However, these approaches only control the symptoms and, as serious investigation of the Rashway project showed, they do not work. They provide simplistic approaches to very complex problems and at the same time punish those who do not fit the mainstream norms of success or behavior.

The logic of free market, competitive individualism leads to the inescapable conclusion that the disadvantaged and deviant, including troubled youth, are responsible for their own plight. Just as each individual is responsible for taking the opportunity of the abundance of 
America and to achieve individual success, each is responsible for failure. If one accepts this "psychology of abundance," there can be no explanation for deviance or failure except a lack of commitment or will to succeed.

To suggest that minority youth can freely transcend their socioeconomic and familial environment if they really want to, or that they alone are to blame for their failure and difficulties with the dominant society, is unrealistic and cruel. Worse, it narrows the approaches for helping them to punishment as deterrence, isolation from society to prevent their transgression against others, and rehabilitation after they are already in trouble. They often cannot "pull themselves up by their bootstraps" because they have no boots.

\section{Culture-and-Personality}

When minorities are in conflict with dominant society, most assume it is a matter of "economics" or "politics" - the distribution of scarce resources or power. While both are very important, there is a more fundamental, unconscious clash occurring at the cultural and psychological level (Weaver, 1975). For example, during the youth and civil rights movements of the $1960 \mathrm{~s}$, many resorted to political and economic labels to explain the phenomena. Blacks were economically disadvantaged and, therefore, once they could have their fair share of the socio-economic pie, the conflict would be resolved. Youth were malcontents who were influenced by radical political philosophies such as Communism. Once they left the ivory towers of academia and entered the "real world," they would grow up and settle down.

While there are political and economic factors involved in these confrontations, it could be argued that they were secondary to the crosscultural clashes. Blacks were concerned about cultural oppression as much as political and economic oppression. In Mead (1970), and Reich (1970) youth were identified as being part of a counterculture with values, beliefs, and behaviors that were in stark opposition to those of the mainstream culture. The primary battle was between cultures with concurrent political and economic implications. Most participants were not the poor or the politically inspired. They were American with a different cultural perspective than that of the dominant culture.

Like a rubberband, the countercultural movements of the late 1960 s went in the opposite direction of the mainstream culture. Today, the rubberband has snapped back to the dominant culture in terms of values, beliefs and behaviors. Many of the current approaches to child care that are impacting minority youth are a direct result of this backlash and, to understand them fully, we must take a culture-and-per- 
sonality perspective, after which the focus can move to the economic and political. This is a much more complete approach but it best helps explain the framatic reversals in child care, especially in terms of the minority child.

The concept of culture is often misunderstood because there are thousands of definitions for "culture." Almost all include the notion that culture is acquired or learned by growing up in a particular society. We know it exists because people in the same society have roughly the same values, beliefs, thought patterns, ways of perceiving the world, and behavior. Something causes this to happen which we may label culture.

Culture is somewhat like the term "personality" and, in fact, it is difficult to separate personality from culture. A teacher may help all children to write in a similar way but each will have his or her own particular handwriting. Culture causes all members of a society to share ways of thinking, perceiving, and behaving but each person will differ somewhat from the norm.

Personality is always a generalization or stereotype. When we describe someone's personality, we are speaking of his or her characteristic ways of behaving which were learned during the formative years and carried into adulthood. Fred might be described as an "extrovert" because he usually behaves in an outgoing, gregarious manner and enjoys interacting with others. This generalization is very useful for explaining his behavior and predicting what he is likely to do in certain social situations. However, at times, perhaps when he is alone, he is rather withdrawn and shy or an "introvert."

Culture is also a generalization and stereotype. We can describe some cultures as "secular" and others as "religious," while there are elements of both in all cultures. It is really a matter of degree. Asian cultures are generally more passive than Western cultures and harmony may be more important than change in most nonwestern cultures. These adjectives are useful generalizations because they help us to explain the behavior of most people in the society and allow us to predict behavior under certain circumstances.

Sigmund Freud divided the mind into two interrelated parts with the subconscious controlling the conscious. Further, he suggested the mind is like an iceberg with the conscious comprising only the small tip above the water level of awareness. The greater part is hidden or unconscious, yet it often controls our conscious thoughts and behaviors.

This same metaphor can be applied to culture which can be divided into "internal" and "external" culture. External culture is the small tip of the iceberg and would include such overt manifestation as customs, behavior, language, and the artifacts of culture such as art, music 
and literature. The greatest part of culture is hidden below the water level of awareness. Internal culture includes implicitly learned thought patterns, values, beliefs, and perceptions. To understand external culture, we must raise internal culture to conscious awareness perhaps through the trauma of leaving our own culture and entering another (Hall, 1976).

Just as we acquire our basic personality during the formative years as we interact with others, we learn our culture. We come into this world somewhat like brand new computers, and culture is the program given to us by our society. Out of the vast array of stimuli and information that bombards us, our culture teaches us which information or "input" gets into our heads and via which sensory channels. Like a lens, it selects out what we will attend to. This information is then organized according to priorities or values which are ranked by the society. Our "input" or behavior cannot be understood unless we know how we are programmed.

To be human is to have a culture. In 1800 there was a 12-year-old boy who ran naked in the fields of the French countryside. He ate raw meat and howled at the moon at night. When he was captured he was seen around wolves and it was assumed that he must have been raised by wolves. This was the only logical explanation of his animalistic behavior.

Today we know that Itard's wolf-boy (Malson, 1972) was not raised by wolves. He was simply abandoned by his parents as an infant and, by some miracle, managed to survive outside a human culture. Thus, he took on none of the characteristics we would call "human." Very little, if any, human behavior is instinctual. We have the longest maturation period of any species and must learn or be programmed by our society to become human. The analogy between infants and unprogrammed computers is really not that farfetched.

Culture and personality are interrelated and mutually interdependent systems. You touch a culture at one point and it reverberates through the entire system and, in turn, affects personalities within the society. Consider the impact of the auto on the American culture including the family, courting behavior, values, the subculture of youth, and so forth.

An economic or political change will obviously have repercussions throughout a culture. Over a period of time, there will be an impact on internal culture - values, beliefs, perceptions, and thought patterns. However, the initial impact will be on external culture: behavior. The internal part of culture is slow to change because it is primarily unconscious. When there is a conflict or dissonance between behavior and beliefs, beliefs will change to bring about consonance (Festinger, 1957). 
One cannot deny the behavior and, in our striving for consonance between beliefs and behavior (internal and external culture), only the beliefs may change.

On the other hand, if we can change values, thought patterns, beliefs, or perceptions, we can change behavior (McClelland, 1967). But, this is much more difficult. Take an elderly Italian in Philadelphia who has been there since the age of 15 . He is now 85 years old and has little accent to his speech and appears to be an average, mainstream American. However, have a few glasses of wine and some pasta with him, and it becomes apparent that he is still very Italian, especially in terms of his ways of thinking, beliefs, values, and perceptions of the world. His behavior has changed, but there are still strong elements of the culture he brought with him from Italy buried in his unconscious mind.

Surely, there are differences between minority and mainstream Americans that are culturally based. With Hispanics and Asians, this is obvious. While the black American experience is much further removed from African cultural roots, the isolation and insulation of blacks from the mainstream through racism certainly caused them to share a cultural experience unlike that of white Americans. The ghetto walls not only kept blacks inside, they kept whites out.

True pluralistic integration has not taken place and even the modest desegregation that exists today is not more than a few decades old. Furthermore, child-raising practices which instill internal culture, are passed down from generation to generation and change very little (Cobbs \& Grier, 1968). Many of us will raise our children as our grandparents raised our parents. Thus, the black American culture or subculture which existed 100 years ago is still learned unconsciously by black American youth today.

This acceptance of differences between minority and mainstream culture was openly acknowledged and celebrated during the various identity movements of the late 1960s, yet, today it is denied under the rubric of "colorblindness" and "equality." In less than 20 years culture has become irrelevant to child care. Nonmainstream children are not only denied their cultural differences, they are forced to fit the norms of the mainstream society.

\section{Melting Pots And Cultural Cookie Cutters}

Most Americans are unaware of their own culture and take it for granted. In fact, some might argue that there is no such thing as the American culture in the sense that there are French, British, Asian, African, and Latin American cultures. "Melting pots," "salad bowls," 
and "soups" are often used as metaphors which illustrate the apparent mixture of many cultures rather than any distinct American culture. Not only is the concept of culture misunderstood or ignored, the average American does not even believe he has a culture.

Americans do not systematically study their own culture. In anthropology departments, scholars write papers on Africans, Asians, and sometimes subcultural groups within the United States, but little is written about the mainstream or dominant culture. Some of the best studies of the American culture have been written by foreigners such as Alexis de Tocqueville or Gunnar Myrdal (1948, 1954).

America's formative years were unlike those of European states. There was no drawn-out developmental phase during which the nation/ state and nationalism emerged from a feudal period, evolving from villages and city/states. The American nation began abruptly with the immigration of northern Europeans from the Old World who left their homes, extended families, titles and cultures behind to enter the New World.

During this period, they were isolated and insulated from the rest of the world by the two oceans. This was not simply a matter of geography. Settlers preferred to be removed from the rigid class system, political and religious oppression, corruption, and violence of the Old World. This was articulated clearly in George Washington's Farewell Address when he asserted that the U.S. wanted to remain uninvolved in the wars going on in Europe. In the 1820s, the Monroe Doctrine further warned that European nations should stay out of the western hemisphere. Isolationism was a matter of public policy.

Early in the national psyche the habit of not examining the American culture was the accepted practice. There was primarily a one-way flow from the Old to the New World. As immigrant children entered the public education system, with the encouragement of their parents, they gave up the culture of the Old World including its languages, class assumptions, perceptions, and ways of dealing with the social and physical environment. Indeed, immigrant parents often learned better how to cope with the new environment by observing their children who were free of the Old World cultures (Mead, 1970).

Studies of Peace Corps Volunteers, businessmen, and other overseas sojourners find that a principal result of their experience is that they become more conscious of their own culture. As long as we are surrounded by people who share our values, perceptions, ways of thinking, beliefs, and behaviors, we take them for granted. Ironically, by leaving our culture and being immersed in another, we become more aware of our own culture. Even Fela, the highest paid jazz artist in the world, who comes from Nigeria, once claimed that he did not know 
what it meant to be an African until he left Africa. During the formative years of the U.S., Americans did not have this experience. In fact, they wanted to be isolated from other cultures.

It is very difficult for Americans to understand how the personalities of others are shaped by their culture because so few Americans are aware of the impact of their own culture on their personalities. Just as Western psychology assumed that the individual exists outside the context of a community or culture (Doi, 1971), Americans often fail to appreciate how one is affected by cultural experiences. This fits nicely with a philosophy of political and economic liberalism, individualism, self-reliance and independence.

An unquestioned metaphor which perpetuates a cultureless selfimage is the so-called American "melting pot." It describes a process of assimilation and an assumption of a truly pluralistic society whereby immigrants threw their respective cultures into a pot. The mixture was stirred and heated until it melted down into a harmonious blend of cultures from all over the world with no distinct or dominant culture.

While there is some truth to this, the melting pot is mostly a myth. One would have to search diligently to find equal contributions from all the cultures brought to these shores. Immigrants from Latin America, Asia, Africa, and even southern Mediterranean cultures do not find the richness of their cultures melted evenly into this pot. They melted no further than tacos, chop suey, shish kebab, and pizza - two of which were invented in this country.

Rather than a melting pot, there has been a cultural "cookie cutter" with a white, male, protestant, Anglo-Saxon mold. The price one paid to enter the mainstream or dominant culture was to give up those cultural characteristics which did not fit this mold. This is not a process of "cultural pluralism" but, instead, "cultural homogenization" or, in political terms, "cultural imperialism."

While all might be free to acculturate or learn the norms and behaviors of the mainstream, the ability to enter was controlled by the dominant culture. Acculturation is a process of learning or acquiring another culture while assimilation is a matter of being accepted as a member of another culture. Assimilation was determined by those with political, social and economic power as in many colonial societies (Rich \& Ogawa, 1971). To be accepted, one had to discard all cultural characteristics which did not fit the cookie-cutter mold of Anglo-America.

Mainstream folk often self-righteously affirm the melting pot myth with statements such as: "My Grampa Stripinski came to this country at the turn of the century - an illiterate Polish Jew who couldn't even speak English. He worked hard as a laborer in the streets of Milwaukee, and look at his family today! Every grandchild has a college education! 
Now, why-in-the-hell can't blacks and Puerto Ricans do the same thing?"

This is a perfectly reasonable and legitimate question, if we had a melting pot. It suggests that if Grampa Stripinski could move his family into the middle class, all others could do likewise, unless they simply did not have the determination, fortitude, and character to do so. Those who could not enter the mainstream really did not want to and were therefore responsible for their own plight in the American society.

But, did Grampa Stripinski and his immigrant family simply melt into the pot? If he was typical of many Jews coming at the turn of the century, he may have temporarily suspended the public practice of his Jewish faith to blend into the Protestant community. Also, there was a great deal of overt anti-semitism during those days, especially in the midwest. This is a well-documented pattern of assimilation described by such eminent researchers as Harvard's Will Herberg in his classic study, Protestant, Catholic, Jew.

If he was typical of many immigrants coming at the turn of the century, he probably did not allow his children to speak Polish. The better they learned English without an identifiable accent, the quicker they moved into the mainstream culture. He may have even changed his name to make it a bit more Anglo. Today, the Stripinskis might be the Stevens or the Stevensons. Even Ronald Reagan's grandfather changed his name.

Obviously, Grampa Stripinski did not simply throw his culture into the pot. He gave up those cultural characteristics that did not fit the cookie-cutter mold. The reason blacks and Puerto Ricans could not easily enter the mainstream is not that they chose to remain isolated from the dominant culture or lacked the character typical of white immigrants. They could not change their skin color or hair texture to fit the mold. They were identifiably different and thus were not allowed to assimilate. While this may have been true of first generation white immigrants who could not hide their accents, their English-speaking children quickly assimilated. Regardless of the quality of English or the mastery of mainstream values and behaviors, nonwhites and their offspring were not permitted to assimilate.

The cookie-cutter mold still exists today. Over 70 percent of all Americans could be classified as Protestant and the Episcopalians (Church of England) are the richest in terms of per capita income. In 1960 there was a tremendous reaction against a Catholic running for President. Quarters were circulated with red caps painted atop George Washington's head with finger nail polish. With a red skullcap, Washington takes on an uncanny appearance to (then) Pope John XXIII. 
The message was that if Kennedy were elected President, the Pope would run the country. He was elected, and the Pope did not run the country. But, why was this an issue if Americans believed in a melting pot? Surely, there were many other Catholics who could have been elected President before 1960 .

The greatest number of Americans can trace their ancestry back to the British, followed by Germans and Irish. There is no official national language in the U.S. and yet English usage has predominated. The Continental Congress once met to discuss what language ought to be used when conducting business. In those days, most delegates spoke German. The journalist, Benjamin Franklin, even published his first newspaper in German. Rumor has it that the British delegates to the Continental Congress bribed a few of the Germans, and English won out. In spite of the common use of German and even the Prussian Horce Mann's impact on education, the cookie-cutter mold of Anglo-America determined the unofficial language of government.

Today, there is a very emotional backlash against bilingual education and the use of Spanish. Seven states have voted to make English their official language and there is a strong movement afoot to legislate English the official language of the nation. Why in the 1980s is this an issue, if we believe in the melting pot?

In 1980, voters in Dade County, Florida passed a referendum outlawing the use of Spanish on street signs. If the object of a stop sign is to prevent a motorist from hitting another, who cares what language it is written in? On the other hand, if the object of the stop sign is to force one to read English - to fit the cookie-cutter mold - then it ought to be in English.

There have been many times and places in America when the majority of a population did not speak English, yet we did not have images of a separatist Montreal in mind. It was primarily transitory because they wanted their children to learn English. Hispanics today also want their children to learn English. Otherwise, they will be trapped forever in Miami or Los Angeles. These families want to melt, but they also may prefer to retain Spanish with their English. This is not a threat to the idea of a melting pot, pluralistic society. It does undermine the cookie-cutter mold.

\section{What Is "The American Culture"?}

The dominant or mainstream American culture is still AngloAmerican in terms of socio-economic and political power, accepted norms of behavior, values, beliefs, and ways of thinking. The average American is white, middle class and urban. And, the behavior which is deemed normal is that of the mainstream. Institutions, such as 
schools and child care centers, both consciously and unconsciously accept and enforce the norms of the dominant culture regardless of the impact on the nonmainstream child. Indeed, the cookie-cutter operates daily in these institutions.

We can accept this definition of the American culture without denying the great diversity which exists in the U.S. and the changes that have taken place over the past two decades. Certainly, there is more ethnic diversity in America than in any other country on the globe except the Soviet Union. In the 1984 Presidential election, a black ran for President and a female Italian Catholic ran for Vice President. Nevertheless, the average American fits the cookie-cutter mold. Identifiable ethnic minorities might be considered subcultures, not because they lack the richness or depth of the mainstream, but because they are dominated by the mainstream culture.

It is asserted that Americans are basically watered-down or underdeveloped northern Europeans because the early settlers were primarily from the north of Europe. Large waves of southern European immigrants really did not come until the nineteenth century. However, this is as erroneous as the melting pot assumption. The first settlers were hardly "typical" northern Europeans. They were highly mobile, willing to travel to the New World knowing that over 20 percent would die enroute. The average European was living in a small house as his father and father's father, and one would have to be a bit unusual to start a journey knowing there was a good chance of dying along the way. These were high-risk takers.

Most were Calvinists and Puritans who had a fundamental religious belief that God rewards those who work hard and it is up to each individual to earn status in society based upon personal effort, not family background. Socio-economic mobility was anticipated in a society without titles or nobility, monarchs, a rigid class system, extended families, or gross disparities in wealth and opportunity. This was a bizarre belief given the reality that the likelihood of rising above one's social or economic station at birth was almost nil in Europe in those days.

Early American colonists were really outcasts, fleeing religious and political oppression and persecution in Europe. Some others left to avoid fighting the endless wars. Today, they would be considered draft-dodgers. And, some were criminals who were exiled to the New World. To view these settlers as simply typical northern Europeans would be a gross distortion of reality.

Many of their behaviors and customs - external culture - resembled typical northern Europeans, but in terms of internal culture, they were atypical. The mainstream American values and beliefs found 
today date back to these formative years and most have remained unconscious and unquestioned until the turmoil of the $1960 \mathrm{~s}$. When these values and beliefs were planted in the American soil, they flourished and became even more significant than anywhere in Europe.

Colonial America was isolated from the wars of Europe. The land had unlimited natural resources, a coastline with hundreds of natural harbors, and a continually expanding economy. There was a small population and a desperate need for manpower. A psychology of abundance developed based upon the abundance of opportunity to succeed in the New World. If one was willing to work hard, there was a strong probability of economic advancement. Given the abundance of resources and opportunities, only those who were unwilling to work would fail. If God rewarded those who worked hard, those who failed were obviously responsible for their own fate. The slogan might have been, "cursed are the poor" with this combination of physical environment and the Protestant Work Ethic.

The values and beliefs that are most important in any culture are those that are rewarded. The Work Ethic was highly reinforced in this environment. Had colonists landed in Antarctica, it is unlikely that individual achievement, earned status, competition and hard work would have been important values and beliefs. Not only would they have gone unrewarded, they might inhibit survival. Affiliations with others, an extended family to depend upon, and cooperation would have been higher on their hit parade of values.

Furthermore, had the first settlers not shared the Work Ethic, it is unlikely that an American culture, as we know it today, would have developed. It was the combination of values and physical environment that allowed for the formation of a culture we may term "American," as distinguished from most other cultures around the globe.

It was no accident that the Bible of capitalism, Adam Smith's Wealth of Nations, was published in 1776 . Free enterprise, market capitalism and political liberalism were built upon assumptions of individual achievement, social mobility within a class system, and an anti-government philosophy. They also grew in the greenhouse environment of America with an abundance of natural resources, limited population, and continually expanded economy. Americans had to extend themselves into the rest of the world to export their agricultural products and insure their economic growth. Thus, Freedom of the Seas was added by Thomas Jefferson to the foreign policy of isolationism. It was clear that only to guarantee continued domestic growth would Americans involve themselves beyond their own shores.

A self-righteousness developed based upon the tremendous success of these early colonists. In the minds of many, it was obvious that the 
New World was chosen by God. The evidence was the political, economic and social success of these Americans who were not mired in corruption, war, despotism, and a riding class system which imprisoned most in poverty. The disposition to be unconcerned about the rest of the world and to perceive it as evil, was established during these formative years. A melodramatic good-guys versus bad-guys perception - the morally strong American against the immoral world - emerged with its dualist absolutes of Heavens and Hells, Angels and Devils, and later the Free World and the Communist World.

When opportunities became more limited on the East Coast, there was a movement to the West. Nuclear families in covered wagons survived on the frontier with their "cowboy values" - self-reliance, rugged individualism, and independence. The romantic heroes of this period were pioneer families and lone adventurers such as Daniel Boone, Davey Crockett, and Paul Bunyan. Americans have always admired men of action who have achieved success through their own individual efforts. Statues throughout the country which are erected to commemorate historical events usually depict individuals in action or ready for action. We remember the War of Independence with a Minuteman carrying his rifle, rather than a group of old men sitting around a table signing a Declaration of Independence. In many other countries, statues of thinkers, artists, poets, and writers abound.

True success is individual success. No politician today will stand before the masses and acknowledge all those who helped him achieve his victories. Rather, he will portray himself as Abe Lincoln raised in a log cabin. Horatio Alger, Rudolph the Red-Nosed Reindeer, and Rambo all perpetuate the myth of the one hero. Even the beloved Jonathan Livingston Seagull is a happy seagull who separates himself from his flock. He becomes the Charles Atlas of the seagull world, practicing his swoops and his dives until he surpasses all other seagulls. He then returns to his flock to teach all the others how to really fly. Is this not the American Dream?

When a grade school teacher asks her children, "Who knows the answer to this problem" the children frantically wave their arms to get her attention. Consciously, she is teaching math, but unconsciously she is programming their little cultural computers. Each time the child waves an arm, the child is learning competition. It is not simply competition, it is individual competition because each child loves it when the smart child on the other side of the room gives the wrong answer. Even team sports, such as football, celebrate the myth of individualism. On Monday morning, we discuss Sunday's game in terms of the quarterback or the player who scored a touchdown, totally ignoring the rest of the team. And the television camera focuses in on these lone heroes 
who dance in victory or spike their ball. And, the crowd goes wild as if he made the touchdown all by himself, totally ignoring a half dozen other players with cleat marks up their backs.

Of course, the corollary to the myth of individual success and achievement is the belief that one is individually or personally responsible for failure. This is the only logical explanation given the melting pot myth, the psychology of abundance, and the assumption that all could be individually successful. When unemployment peaked in the early $1980 \mathrm{~s}$, American laborers did not organize to change their government. In fact, they overwhelmingly supported President Reagan in his 1984 re-election bid. In Europe and many other areas of the world, workers would blame their leaders for their unemployment and try to change their government, but in the U.S. workers apparently blamed themselves for their plight. Alcoholism, impotency, and suicide increased among newly unemployed laborers. Americans feel individually responsible for their failures.

Certainly the poor and disadvantaged are not solely responsible for their lack of success, yet Americans often do blame them and they blame themselves (Weaver, 1975). During periods of overall prosperity, as during the $1960 \mathrm{~s}$, Americans may become more understanding and benevolent towards those who are less fortunate. But, during periods of a restrictive economy, such as the 1970s, a self-centeredness sets in to supersede the altruism.

The current mood is one of individualist dog-eat-dogism. The assumption is that everyone has an equal opportunity to succeed and no special advantages ought to be given to those who fail. The families of children who fail are held accountable, not the schools or other institutions of the society. And, in some cases, the children alone are blamed for their failure. Rather than being helped to overcome their socioeconomic misfortunes, they are treated as contaminants to be isolated, punished and sometimes modified so that they may fit back into the overall society.

\section{"Color-Blindness" And Cultural Homogenization}

Americans believe in the melting pot but, in practice, they apply the cookie cutter. For those who could fit the mold, socio-economic advancement in a class society was possible based upon one's individual efforts. Status was earned or determined by what one did. Being male or female, black or white, Protestant or Catholic, is theoretically irrelevant to one's position in the society if, and only if, one could fit the cookie-cutter mold.

The most common verb in standard American English is "to do," 
perhaps because doing is so important in a society without ascribed status or roles. What one does even determines identity. Each semester at The American University I ask students to tell me who they are in a few sentences. Almost all tell me what they do - "I'm a biology major" or "I'm completing my masters in communications." Ask people at a cocktail party, "Who are you?" Most will tell you what they do and then ask, "What do you do?" as if what you do is who you are.

Certainly, lack of respect for the elderly and the unemployed is related to their diminished status and identity when they no longer "do" anything. These nonproductive people often find their own selfesteem dramatically lowered when they stop doing. Because of the myth of individual responsibility for success or failure, they sometimes feel guilty for their own plight. Some feel worthless and may even give up on life. This perhaps explains why suicide and alcoholism increased among the newly unemployed during the recession of the early 1980s. And there was an upsurge of impotency among these former workers. Even "manhood" is earned and is affected by no longer being able to do.

Unlike laborers in Europe, American workers did not blame their government for their dire situation. They did not organize to change the government but instead strongly supported the Administration. Suicide, alcoholism, and impotency all suggest these victims blamed themselves. Retirement is almost a vulgar word in America while in other cultures it is welcomed. The average lifespan of a Boeing Aircraft retiree is $\mathbf{1 8}$ months. Is it any wonder that there is a very strong push to eliminate retirement in the United States?

Identifiable minorities, those who could not fit the mold, were treated as castes within the class system. Nonwhites were ascribed status and identity based upon who they were, not what they did. It was not a matter of individual achievement or the acquisition of wealth. Less than 25 years ago, a black millionaire could not sit next to an illiterate white laborer in a southern diner.

While this apartheid-like system no longer exists, we have moved to the opposite extreme and forced minorities to deny who they are, including their own cultural and racial differences. In many ways, "color blindness" is as oppressive to identifiable minorities as the overt racism of the pre-1960s. This is especially true for children in child care facilities today.

To explain this apparent contradiction between color-blindness and ethnic or racial oppression, we must go back to the 1960 s. When we think of the changes of that period, many consider the Civil Rights Act, the 18-year-old right to vote, and other such political accomplishments. However, the most sweeping changes were primarily cultural. 
Assumptions held by Americans for hundreds of years were questioned by the vast majority. At the top of the list would be the melting pot assumption of how one enters the mainstream of the American society.

The first sit-ins were actually efforts to get into the melting pot and in no way challenged the myth or the process. This was a quantitative protest similar to the labor movement. Laborers and blacks wanted their fair share or quantity of the socio-economic pie. After workers established the right to organize for fair salaries, benefits, and practices, they blended into the middle class of America and proved that, given an equal opportunity, they could be successful. Blacks wanted the same right of entrance. However, they could not give up their differences to fit the cookie-cutter mold as white laborers did. The price of entry was exorbitant and impossible to pay.

No one really challenged the reality of the cookie-cutter process or questioned the price of entry until the mid-1960s when "Black Powerism" arose. With the assertion of black identity the civil rights movement became qualitative. Blacks not only established the right to maintain their cultural and racial identities and still enter the mainstream; they also questioned the worth of the American pie if it meant continually earning identity and self-esteem in a dog-eat-dog society.

This was surely the first existential movement in American history and is the basis of all identity movements since then. Women's Liberation, Chicano Liberation, Gay Liberation, and all other such movements assert the right to be different and still have their fair share of the American pie. They refuse to pay the price of giving up or denying their cultural and group identities. Who they are is as important as what they $d o$.

Up to the time of the Black Power movement, racists and liberals perceived themselves as opposites. Racists believed that those who are genetically different are therefore inferior. Liberals assumed that all are equal and there are no differences between people. On the surface, this appears just and fair to everyone, including minorities. But, there was an unspoken corollary which might be stated this way: "There are no differences between whites and blacks. Given an equal opportunity, they would be just like us." The norm is "us" or the white, Anglo-Saxon, Protestant male. This is again the cookie-cutter assumption, not a melting pot. Identifiable minorities are perceived as pathological or underdeveloped white people.

The liberal position is roughly akin to color blindness in that it denies the reality and right of people to be different than the cookiecutter mold. From a cultural standpoint, it argues for homogenization of cultures. From a political standpoint, it is a form of cultural imperialism. 
Black Powerism posted a third perspective which asserted the right to be different and still have an equal opportunity to enter the mainstream. It was not anti-white, but instead pro-black, and advocated genuine pluralism in the United States. If we truly practice the melting pot, why couldn't one be black and still have equal access to the socioeconomic and political system? Why do successful women have to behave like men or deny their femininity? And, why couldn't Hispanics retain their rich cultural heritage and Spanish while working within the dominant society where they would necessarily communicate in English?

This third position acknowledges that there are cultural, racial, and sexual differences among Americans, yet these differences do not imply inferiority or superiority. True pluralism accepts differences whereas liberalism and color blindness denies them. The richness of a melting pot is its diversity and the union of a variety of cultures and identity groups. The cookie cutter forces individuals to cast off those cultural characteristics which do not fit the mainstream mold to produce a homogeneous society.

This approach has been described as "realistic humanism" (Weaver, 1981) or "diunitalism" (Jackson, 1979) in contrast to the deficit approach of the color blind. Some would argue that the current perspective in mental health is actually a "backlash" against this third perspective. The deficit hypothesis in mental health is based on the assumption that minorities, and especially blacks, are simply deficient in opportunities, their families are pathological, and their communities are unlike those populated by mainstream white Americans. Given these assumptions, the society ought to remedy the deficiencies and minorities will then be "the same as" (equal to) whites.

The diunital model would accept the difference between minority and mainstream cultures. To be helpful to minority clients and communities, assistance should be offered within the context of their cultures. Further, the differences between minority and mainstream cultures produce a variety of approaches which strengthen the overall society. Carried to a somewhat romantic extreme, the heterogenous mix becomes a union of opposites and the whole is greater than the sum of the parts. Diunitalism provides an alternative to the backlash of colorblindness and replaces homogeneity as a goal with heterogeneity. In effect, it simply asserts that Americans should practice what they preach: melting pot pluralism.

The culture of group child care is overwhelmingly white. Most child care professionals are white, the values determining appropriate behavior and therapy are white, and child care work often amounts to forcing all children to fit a white, middle-class cultural mold. The 
population of children needing group care is steadily turning nonwhite and the impact of the white group child care culture is devastating in terms of its impact on their self-esteem, self-image, and ethnic or racial pride. It is downright destructive to their mental well-being.

Behavioral psychology with its emphasis on overt behavior, quantification, and a preoccupation with manipulating "appropriate" behavior, leads child care workers to ignore the impact of culture on personality. In fact, behaviorists never have actually developed a theory of personality. They typically draw analogies between human behavior and animal behavior in controlled social environments, totally disregarding the impact of culture on behavior. On the other hand, behaviorism provides an Apollonian approach to child care management and funding which lends itself nicely to observable and measurable studies.

The behavioral approach to child care abets the cultural shaping to the white mold. Instead of focusing on who the child is in the context of his or her personal and cultural experiences, the child care worker is expected to observe, record, and control what the child does, as if children grow up removed from the influences of race and ethnicity. Of course, the institution and staff have a culture which is taken for granted and unconsciously imposed upon all children. They are compelled to accept and understand the institution's white culture and, in turn, nonwhite children are expected to give up or repress their culturally different behavior and values. The minority child's culture is not simply viewed as "different." Rather, his or her culturally determined behavior is often perceived as abnormal, inappropriate, and an impediment to good therapy. This child's culture is not simply ignored, it must be denied.

Central to good child care is an assumption that the child's selfesteem and self-image ought to be enhanced. The minority child's selfesteem and self-image is already low when entering the institution. A repeat of Kenneth Clark's famous 1940's study of children's self-image demonstrated that feelings of racial inferiority among black children are as strong now as forty years ago (Forster, 1987, 3). Preschool black children were again given black and white dolls which were identical except for color. They were asked which doll they wanted to be, which was "bad" or "nice," which was a "nice color," and which they would like to have. Two-thirds of the black children preferred the white dolls, the same percentage as in the 1940's study.

Surely entering a white institution where the rules and expectations for appropriate behavior are white only serves to further undermine the self-image of the minority child. If a large percentage of children are culturally different than the staff, the burden of crosscultural understanding ought to be the burden of the staff, not the 
children. The staff needs to be aware of the repercussions of cultural domination, of cross-cultural adaptation, and of ways to use cultural differences to enhance the psychological well-being of the child. However, anthropology, sociology, and even social psychology are often considered extraneous to staff discussions and professional conferences.

Lastly, child care professionals seldom are encouraged or rewarded for posting philosophical questions regarding their work. These questions must be raised if we want to effectively help all children and avoid harming the minority child. Are we forcing nonwhite children to fit white norms of behavior? What do we really mean by "appropriate behavior" and might it actually amount to white, mainstream behavior? Can we really "empathize" with the child who is culturally different? Are role models provided for minority children and are nonwhite role models important for mainstream children? These are much more than tangential, philosophical issues. They are indeed ethical questions which ought to be uppermost in the minds of everyone involved in child care, but especially for those on the "front line."

\section{REFERENCES}

Cobbs, P. M. \& Grier, W. H. (1968). Black rage. New York: Basic Books, Inc.

de Tocqueville, A. (1948). The recollections of Alexis de Tocqueville. London: The Harvill Press.

Doi, T. (1971). The anatomy of dependence. Tokyo: Kodansha International, Ltd.

Festinger, L. (1957). A theory of cognitive dissonance. Stanford, CA: Stanford University Press.

Forster, M. (Winter, 1987), The random sample. Child Care Work, 5, (4), 3.

Harrington, M. (1963). The other America: Poverty in the United States. Baltimore, MD: Penguin Books.

Hall, E. T. (1976). Beyond culture. New York: Doubleday.

Jackson, G. G. (1979, August). The roots of the backlash theory in mental health. The Journal of Black Psychology, 6 (1) 17-45.

James, D. B. (1972). Poverty, politics, and change. Englewood Cliffs, NJ: Prentice-Hall, Inc.

Krueger, M., Lauerman, R., et al. (1987) Professional child and 
youth care work in the United States and Canada: A report of the NOCCWA research and study committee. Journal of Child and Youth Care Work, 3, 17-31.

Malson, L. (1972). Wolf children and the problem of human nature. New York: Monthly Review Press.

McClelland, D. C. (1967) The achieving society. New York: The Free Press.

Mead, M. (1970). Culture and commitment: A study of the generation gap. Garden City, NY: Natural History Press/Doubleday \& Company, Inc.

Reich, C. A. (1970). The greening of America. New York: Random House.

Rich, A. L. \& Ogawa, D. M. (1982) Intercultural and interracial communication: An analytical approach. In L. A. Samovar \& R. E. Porter (Eds.), Intercultural communication: A reader (pp. 43-49). Belmont, CA: Wadsworth Publishing Co.

Rowan, C. (1986, December 23). Behind the resurgence of racism. The Washington Post, A23.

Ryan, W. (1971). Blaming the victim. New York: Collier Books.

Schiller, H. (1971). Mass communications and American empire. Boston: Beacon Press.

Weaver, G. (1981, February 2). The cutthroat college generation. The Washington Star, p. A11.

Weaver, G. (1975). Police and the enemy image in black literature. In E. C. Viano \& J. H. Reiman (Eds.) Police and Society (pp. 139-147). Lexington, MA: Lexington Books. 
